\title{
Roseomonas pecuniae sp. nov., isolated from the surface of a copper-alloy coin
}

\author{
Correspondence \\ Paula V. Morais \\ pvmorais@ci.uc.pt
}

\author{
André Lopes, ${ }^{1}$ Christophe Espírito Santo, ${ }^{1,2}$ Gregor Grass, ${ }^{2}$ \\ Ana Paula Chung ${ }^{1}$ and Paula V. Morais ${ }^{1,3}$ \\ ${ }^{1}$ IMAR, University of Coimbra, 3004-517 Coimbra, Portugal \\ ${ }^{2}$ University of Nebraska-Lincoln School of Biological Sciences, E141 Beadle Center, Lincoln, NE \\ 68588-0666, USA \\ ${ }^{3}$ Department of Life Sciences, University of Coimbra, Apartado 3126, 3001-401 Coimbra, Portugal
}

Coins are known to carry a transient microbial community, although they are usually made from copper alloys that reduce bacterial contamination. During a survey of the bacterial community of copper-alloy coins from general circulation, a copper-resistant coccoid, strain $\mathrm{N} 75^{\mathrm{T}}$, was recovered among a large number of other isolates and was most closely related phylogenetically to species of the genera Muricoccus and Teichococcus. The genera Teichococcus and Muricoccus each contain a single species (Kämpfer et al., 2003), but these species were recently reclassified in the genus Roseomonas, based on their phenotypic and phylogenetic relatedness, as Roseomonas ludipueritiae and $R$. rosea, respectively (Sánchez-Porro et al., 2009). The alphaproteobacterial genus Roseomonas includes a number of species which are characterized by their typical pink pigmentation, oxidative metabolism and coccoid rod shape, appearing in pairs or short chains (Rihs et al., 1993). At the time of writing, the genus comprised 11 species with validly published names: Roseomonas gilardii (the type species, with the subspecies $R$. gilardii subsp. gilardii and R. gilardii subsp. rosea) (Rihs et al., 1993, 1998;

The GenBank/EMBL/DDBJ accession number for the 16S rRNA gene sequence of strain $N 75^{\top}$ is GU168019.
Han et al., 2003), R. aerilata (Yoo et al., 2008), R. aquatica (Gallego et al., 2006), R. cervicalis (Rihs et al., 1993, 1998), R. fauriae (Rihs et al., 1993) (now considered a later heterotypic synonym of Azospirillum brasilense; Helsel et al., 2006), R. vinacea (Zhang et al., 2008), R. lacus (Jiang et al., 2006), R. mucosa (Han et al., 2003) and R. terrae (Yoon et al., 2007), in addition to $R$. rosea and $R$. ludipueritiae (Sánchez-Porro et al., 2009).

Species of the genus Roseomonas are characterized by having ubiquinone Q-10 as predominant quinone and polar lipid profiles exhibiting major to moderate amounts of diphosphatidylglycerol, phosphatidylglycerol, phosphatidylethanolamine and phosphatidylcholine. The fatty acid profiles contain alphaproteobacteria-characteristic compounds $\left[\mathrm{C}_{18: 1} \omega 7 c\right.$ as the predominant fatty acid in addition to $\mathrm{C}_{16: 0}$ and $\mathrm{C}_{16: 1} \omega 7 c / \mathrm{C}_{16: 1} \omega 6 c$ (summed feature 3)] and the rarely found acid $\mathrm{C}_{18: 1} 2-\mathrm{OH}$. The DNA G+C content is $65-71 \mathrm{~mol} \%$ (Sánchez-Porro et al., 2009). On the basis of the data presented here, we propose that strain $N 75^{\mathrm{T}}$ represents a novel species of the genus Roseomonas.

Strain $N 75^{\mathrm{T}}$ was isolated from the surface of a 50 Euro cent copper-alloy coin. The coin was stamped on R2A medium and incubated aerobically at $30{ }^{\circ} \mathrm{C}$ for 5 days. Isolates were 
purified by streaking on R2A medium and preserved at $-80{ }^{\circ} \mathrm{C}$ in nutrient broth (NB) containing $15 \%(\mathrm{v} / \mathrm{v})$ glycerol. Strain $\mathrm{N}^{2} 5^{\mathrm{T}}$, showing pink-red colonies, was revealed at the time of isolation to be related phylogenetically to the genus Muricoccus and was chosen for further characterization. Muricoccus roseus $(=R$. rosea) DSM $14916^{\mathrm{T}}, R$. aerilata DSM $19363^{\mathrm{T}}$ and $R$. vinacea DSM $19362^{\mathrm{T}}$ were obtained from the Deutsche Sammlung von Mikroorganismen und Zellkulturen GmbH (Braunschweig, Germany) for comparative studies.

The organisms were grown under an aerobic atmosphere and under anaerobic conditions (Genebox) on R2A medium at 30 and $37{ }^{\circ} \mathrm{C}$ for 5 days. The temperature range and optimum temperature for growth were examined in R2A incubated at 5, 10, 15, 22, 26, 30, 35, 37 and $40{ }^{\circ} \mathrm{C}$; growth was examined after 5 days. The ability to grow in the presence of $\mathrm{NaCl}$ was examined in $\mathrm{R} 2 \mathrm{~A}$ supplemented with $\mathrm{NaCl}$ at final concentrations of 1 and $2 \%(\mathrm{w} / \mathrm{v})$ at $30{ }^{\circ} \mathrm{C}$. Cell morphology and motility were examined by phase-contrast microscopy after growth in $\mathrm{NB}$ at $30{ }^{\circ} \mathrm{C}$ for $24 \mathrm{~h}$. The Gram reaction and the presence of cytochrome oxidase and catalase were determined after $24 \mathrm{~h}$ of incubation as described by Smibert \& Krieg (1981). Enzymic profiles were determined using API ZYM and API 20NE test strips (bioMérieux), according to the manufacturer's instructions. Single-carbon-source assimilation was determined using API $50 \mathrm{CH}$ test strips (bioMérieux) with $0.2 \mathrm{M}$ phosphate buffer, $\mathrm{pH} 7.2$, supplemented with $0.3 \%$ $(\mathrm{w} / \mathrm{v})$ agar (Difco), $0.05 \%$ yeast nitrogen base (Difco) and $0.7 \%$ yeast extract (Difco), as described by Morais et al. (2004). Biolog GN2 MicroPlates were also used for characterization of single-carbon-source assimilation, according to the manufacturer's instructions; plates were incubated at $26{ }^{\circ} \mathrm{C}$ and read after 48 and $96 \mathrm{~h}$. The $\mathrm{pH}$ range for growth was examined at $30{ }^{\circ} \mathrm{C}$ in $\mathrm{R} 2 \mathrm{~A}$ medium with the $\mathrm{pH}$ adjusted by the addition of $50 \mathrm{mM}$ MES (pH $5,6,7)$, TAPS $(\mathrm{pH} 8,9)$ or CAPSO (pH 10) (Branco et al., 2004).

Cultures used for polar lipid analysis were grown on TSA at $30{ }^{\circ} \mathrm{C}$ for $48 \mathrm{~h}$. Cultures were harvested and lyophilized and the polar lipid fraction was separated by twodimensional TLC on silica gel $G$ plates (Merck; $10 \times 10 \mathrm{~cm}, 0.25 \mathrm{~mm}$ thickness) using chloroform/methanol/water $(65: 25: 4$, by vol.) in the first direction and chloroform/acetic acid/methanol/water $(80: 15: 12: 4$, by vol.) in the second direction (Collins et al., 1980). Lipoquinones were extracted from freeze-dried cells, purified by TLC and identified by HPLC (Tindall, 1989). Cultures for fatty acid analysis were grown on TSA and in $\mathrm{R} 2 \mathrm{~A}$, in sealed plastic plates, for $48 \mathrm{~h}$ (Morais et al., 2004), and fatty acids were analysed using the standard MIS Library Generation Software (Microbial ID).

The $\mathrm{G}+\mathrm{C}$ content of the genomic DNA was determined by HPLC as described by Mesbah et al. (1989). The 16S rRNA gene was sequenced as described by Morais et al. (2004). The quality of $16 \mathrm{~S}$ rRNA gene sequences was checked manually using the BioEdit editor (Hall, 1999) and sequences were aligned against representative reference sequences of the most closely related organisms, obtained from the Ribosomal Database Project (Cole et al., 2003) and EMBL databases, using the multiple-alignment CLUSTAL_X software package (Thompson et al., 1997). Evolutionary distances were calculated (Jukes \& Cantor, 1969), phylogenetic dendrograms were constructed using the neighbour-joining method (Saitou \& Nei, 1987) and tree topologies were evaluated by performing bootstrap analysis of 1000 datasets (Felsenstein, 1985) by using the MEGA4 package (Tamura et al., 2007).

Strain $\mathrm{N} 75^{\mathrm{T}}$ formed Gram-negative, non-spore-forming, non-motile coccoid cells. After 2 days of incubation in $\mathrm{R} 2 \mathrm{~A}$, colonies were small and pinkish red. Strain $\mathrm{N} 75^{\mathrm{T}}$ had a wide growth temperature range $\left(10-35{ }^{\circ} \mathrm{C}\right)$, with an optimum at about $30{ }^{\circ} \mathrm{C}$ (Table 1 ). Strain $\mathrm{N} 75^{\mathrm{T}}$ was able to grow at $\mathrm{pH}$ 6.5-8 with an optimum at $\mathrm{pH} 7$, which is a narrower range in comparison with $R$. rosea $(=M$. roseus) DSM $14916^{\mathrm{T}}$, which grew at $\mathrm{pH} 6-9$. Strain $N 75^{\mathrm{T}}$ grew aerobically but did not grow anaerobically. Strain $\mathrm{N} 75^{\mathrm{T}}$ did not grow in medium with added $\mathrm{NaCl}$, whereas $R$. rosea DSM $14916^{\mathrm{T}}$ was able to grow in medium with $1 \% \mathrm{NaCl}$ and $R$. vinacea DSM $19362^{\mathrm{T}}$ grew in medium with $2 \%$ $\mathrm{NaCl}$. With the methods used, activities of the enzymes leucine arylamidase, $\alpha$-chymotrypsin, urease and cytochrome oxidase were not detected. Urea hydrolysis was observed in $R$. rosea DSM $14916^{\mathrm{T}}$ but not in $\mathrm{N}^{\mathrm{T}} 5^{\mathrm{T}}, R$. vinacea DSM $19362^{\mathrm{T}}$ or $R$. aerilata DSM $19363^{\mathrm{T}}$.

Assimilation of single carbon sources was not observed using the API $50 \mathrm{CH}$ strip; in fact, only maltose, malic acid and adipic acid gave weakly positive fermentation reactions using API NE (Table 1). When using Biolog GN2 MicroPlates, strain $\mathrm{N} 75^{\mathrm{T}}$ was able to assimilate five carbon sources, while $R$. rosea DSM $14916^{\mathrm{T}}$ assimilated 57 of the 95 carbon sources in the test (Table 1). Like the other species of the genus Roseomonas, strain $\mathrm{N} 75^{\mathrm{T}}$ has $\mathrm{C}_{18: 1} 107 \mathrm{c}$ as the predominant fatty acid in addition to $\mathrm{C}_{16: 0}$ and summed feature 3 (one or more of $\mathrm{C}_{16: 1} \omega 7 c, \mathrm{C}_{16: 1} \omega 6 c$ and iso- $\mathrm{C}_{15: 0}$ 2-OH) (Table 2). All tested strains also showed the production of the hydroxylated fatty acid $\mathrm{C}_{18: 1} 2-\mathrm{OH}$. The fatty acid $\mathrm{C}_{18: 0} 3-\mathrm{OH}$ was produced by strain $\mathrm{N} 75^{\mathrm{T}}$ and also by the other closely related strains ( $R$. rosea DSM $14916^{\mathrm{T}}, R$. aerilata DSM $19363^{\mathrm{T}}$ and $R$. vinacea DSM $19362^{\mathrm{T}}$ ) and was a characteristic that differentiated these species from the other species of Roseomonas (Kämpfer et al. 2003; Sánchez-Porro et al. 2009). It is also interesting to note that $\mathrm{C}_{19: 0}$ cyclo $\omega 8 \mathrm{c}$ was not present in the fatty acid profiles of strain $\mathrm{N} 75^{\mathrm{T}}, R$. vinacea DSM $19362^{\mathrm{T}}$ and $R$. aerilata DSM $19363^{\mathrm{T}}$, whereas it was found in $R$. rosea DSM $14916^{\mathrm{T}}$ and was reported in varying amounts in most type strains of other Roseomonas species (Sánchez-Porro et al., 2009). The fatty acids $C_{17: 1} \omega 7 c$ and 10-methyl $C_{19: 0}$ are present in small amounts in $R$. rosea DSM $14916^{\mathrm{T}}$ but not in strain $\mathrm{N}^{2} 5^{\mathrm{T}}$ grown on TSA. Additionally, in R2A medium, the fatty acids $\mathrm{C}_{17: 0}$ cyclo and $\mathrm{C}_{19: 0}$ cyclo $\omega 8 \mathrm{c}$ were found in the profile of $R$. rosea DSM $14916^{\mathrm{T}}$ but not 
Table 1. Phenotypic characteristics that differentiate strain $\mathrm{N}^{\mathrm{T}}{ }^{\mathrm{T}}$ from the type strains of the most closely related Roseomonas species

Strains: 1 , strain $\mathrm{N}^{\mathrm{T}} \mathrm{5}^{\mathrm{T}} ; 2, R$. rosea DSM $14916^{\mathrm{T}}$ (originally isolated from non-water-damaged building material); 3, R. vinacea DSM $19362^{\mathrm{T}}$ (soil sample); 4, R. aerilata DSM $19363^{\mathrm{T}}$ (air). All tests were performed in this study unless indicated. +, Positive; -, negative; $\mathrm{w}$, weak. All strains contain Q-10 as the predominant ubiquinone.

\begin{tabular}{|c|c|c|c|c|}
\hline Characteristic & 1 & 2 & 3 & 4 \\
\hline Growth temperature $\left({ }^{\circ} \mathrm{C}\right)$ & $10-35$ & $10-40$ & $4-40$ & $5-37$ \\
\hline \multicolumn{5}{|l|}{ Growth at: } \\
\hline $1 \% \mathrm{NaCl}$ & - & + & + & - \\
\hline $2 \% \mathrm{NaCl}$ & - & - & + & - \\
\hline Pigmentation & Pink & Pink & Vinaceous & Pink \\
\hline Morphology & Cocci & Cocci & Coccoid rods & Cocci \\
\hline DNA G $+\mathrm{C}$ content $(\mathrm{mol} \%)$ & 72.8 & 71 & $67.3^{a_{\star}}$ & $72.1^{b}$ \\
\hline Reduction of nitrate to nitrite & + & + & + & - \\
\hline \multicolumn{5}{|l|}{ Assimilation of: } \\
\hline Malic acid & $\mathrm{W}$ & + & - & - \\
\hline Adipic acid & $\mathrm{w}$ & + & - & - \\
\hline Potassium gluconate & - & $\mathrm{W}$ & - & - \\
\hline Hydrolysis of urea & - & + & - & - \\
\hline \multicolumn{5}{|l|}{ Presence of: } \\
\hline Esterase (C4) & W & W & W & + \\
\hline Esterase lipase (C8) & + & + & W & + \\
\hline Leucine arylamidase & - & + & - & + \\
\hline Valine arylamidase & - & - & - & + \\
\hline Cystine arylamidase & - & $\mathrm{W}$ & - & - \\
\hline Trypsin & - & - & $\mathrm{W}$ & + \\
\hline$\alpha$-Chymotrypsin & - & + & - & - \\
\hline $\begin{array}{l}\text { Naphthol-AS-BI- } \\
\text { phosphohydrolase }\end{array}$ & + & + & - & - \\
\hline \multicolumn{5}{|l|}{ Utilization of: } \\
\hline$\alpha$-Cyclodextrin & - & - & - & + \\
\hline Dextrin & + & $\mathrm{W}$ & + & + \\
\hline Tweens 40 and 80 & - & + & - & - \\
\hline $\mathrm{N}$-Acetyl-D-glucosamine & - & + & - & - \\
\hline Adonitol & - & + & - & - \\
\hline D-Arabitol & - & + & - & + \\
\hline Cellobiose & - & - & + & - \\
\hline Erythritol & - & + & - & - \\
\hline D-Fructose & - & + & - & - \\
\hline D-Galactose & - & + & - & - \\
\hline Gentiobiose & - & - & - & + \\
\hline$\alpha$-D-Glucose & - & + & - & - \\
\hline myo-Inositol & - & + & - & - \\
\hline Maltose & - & - & + & + \\
\hline D-Mannitol & - & + & - & + \\
\hline D-Mannose & - & + & - & - \\
\hline Melibiose & - & - & + & + \\
\hline L-Rhamnose & + & + & - & - \\
\hline Sucrose & + & - & + & + \\
\hline Trehalose & - & + & - & - \\
\hline Xylitol & - & + & - & - \\
\hline Pyruvic acid methyl ester & - & + & - & - \\
\hline $\begin{array}{l}\text { Succinic acid monomethyl } \\
\text { ester }\end{array}$ & - & + & - & - \\
\hline
\end{tabular}

Table 1. cont.

\begin{tabular}{|c|c|c|c|c|}
\hline Characteristic & 1 & 2 & 3 & 4 \\
\hline cis-Aconitic acid & - & + & - & - \\
\hline Citric acid & - & + & - & - \\
\hline D-Galactonic acid lactone & - & + & - & - \\
\hline D-Gluconic acid & - & + & - & - \\
\hline D-Glucosaminic acid & - & + & - & - \\
\hline D-Glucuronic acid & - & - & - & + \\
\hline$\alpha$-Hydroxybutyric acid & - & $\mathrm{W}$ & - & - \\
\hline$\beta$-Hydroxybutyric acid & - & + & - & - \\
\hline$\gamma$-Hydroxybutyric acid & - & - & - & + \\
\hline$p$-Hydroxyphenylacetic acid & - & + & - & - \\
\hline Itaconic acid & - & + & + & - \\
\hline$\alpha$-Ketobutyric acid & - & $\mathrm{w}$ & - & - \\
\hline$\alpha$-Ketoglutaric acid & - & + & - & - \\
\hline DL-Lactic acid & - & + & - & - \\
\hline Malonic acid & - & + & - & - \\
\hline Propionic acid & + & - & - & - \\
\hline Quinic acid & + & + & - & - \\
\hline Sebacic acid & - & + & - & - \\
\hline Succinic acid & - & + & - & + \\
\hline Bromosuccinic acid & - & + & + & + \\
\hline Succinamic acid & - & + & - & - \\
\hline Glucuronamide & - & - & + & + \\
\hline L-Alaninamide & - & + & - & - \\
\hline D-Alanine & - & + & - & - \\
\hline L-Alanine & - & + & - & + \\
\hline L-Alanyl glycine & - & + & - & - \\
\hline L-Asparagine & - & + & - & - \\
\hline L-Aspartic acid & - & + & - & - \\
\hline L-Glutamic acid & - & + & - & - \\
\hline Glycyl L-glutamic acid & - & + & - & - \\
\hline L-Histidine & - & + & - & - \\
\hline Hydroxy-L-proline & - & + & - & - \\
\hline L-Leucine & - & + & - & - \\
\hline L-Ornithine & - & + & - & + \\
\hline L-Phenylalanine & - & - & - & + \\
\hline L-Proline & - & + & - & + \\
\hline L-Pyroglutamic acid & - & + & - & - \\
\hline L-Serine & - & + & + & - \\
\hline DL-Carnitine & - & + & - & - \\
\hline$\gamma$-Aminobutyric acid & - & + & - & + \\
\hline Urocanic acid & - & + & - & - \\
\hline Inosine & - & + & + & - \\
\hline Uridine & - & + & - & - \\
\hline Putrescine & - & + & - & - \\
\hline 2-Aminoethanol & - & + & - & - \\
\hline Glycerol & - & + & - & + \\
\hline DL- $\alpha$-Glycerol phosphate & - & + & - & + \\
\hline
\end{tabular}

${ }^{\star}$ Data obtained from: $a$, Zhang et al. (2008); b, Yoo et al. (2008).

that of $\mathrm{N} 75^{\mathrm{T}}$. The polar lipid pattern of strain $\mathrm{N} 75^{\mathrm{T}}$ on two-dimensional TLC revealed the presence of a small number of different lipids in comparison with $R$. rosea DSM $14916^{\mathrm{T}}$ and the type species of the genus, $R$. gilardii (Sánchez-Porro et al., 2009). Phosphatidylethanolamine, 
Table 2. Fatty acid compositions of strain $N 75^{\top}$ and related type strains

Strains: 1 , strain $\mathrm{N}^{\mathrm{T}}$; 2, R. rosea DSM $14916^{\mathrm{T}} ; 3$, R. vinacea DSM $19362^{\mathrm{T}} ; 4$, R. aerilata DSM $19363^{\mathrm{T}}$ (does not grow on TSA). Data were obtained in this study. All strains were grown at $30{ }^{\circ} \mathrm{C}$ for $48 \mathrm{~h}$. Values are percentages of total fatty acids; -, not detected or present at less than $0.5 \%$. Major components for the genus Roseomonas are highlighted in bold.

\begin{tabular}{|c|c|c|c|c|c|c|c|}
\hline Fatty acid & \multicolumn{2}{|c|}{1} & \multicolumn{2}{|c|}{2} & \multicolumn{2}{|c|}{3} & $\begin{array}{c}4 \\
\mathrm{R} 2 \mathrm{~A}\end{array}$ \\
\hline $\mathrm{C}_{14: 0}$ & 0.6 & - & 1.1 & - & 0.5 & 0.5 & 0.7 \\
\hline Summed feature $2^{\star}$ & 0.7 & 0.8 & 2.3 & 1.1 & 0.8 & 0.5 & 1.0 \\
\hline Summed feature $3^{\star}$ & 25.5 & 23.2 & 16.6 & 21.0 & 40.8 & 34.8 & 28.8 \\
\hline $\mathrm{C}_{16: 0} 3-\mathrm{OH}$ & - & - & 2.4 & 0.7 & - & - & - \\
\hline $\mathrm{C}_{16: 1} \omega 5 c$ & 0.8 & 0.9 & - & 0.7 & 0.5 & 0.5 & 0.6 \\
\hline $\mathrm{C}_{17: 0}$ cyclo & - & - & 10.3 & - & 1.5 & - & 10.4 \\
\hline$C_{17: 1} \omega 6 c$ & 0.9 & 4.0 & - & 4.0 & - & - & - \\
\hline $\mathrm{C}_{17: 1} \omega 7 c$ & - & - & - & 2.2 & - & - & - \\
\hline $\mathrm{C}_{18: 0} 3-\mathrm{OH}$ & 1.8 & 1.6 & 6.4 & 2.7 & 2.7 & 2.6 & 2.4 \\
\hline $\mathrm{C}_{19: 0}$ cyclo $\omega 8 \mathrm{c}$ & - & - & 6.5 & 0.8 & - & - & - \\
\hline 10-Methyl $C_{19: 0}$ & - & - & - & 1.1 & - & - & - \\
\hline
\end{tabular}

${ }^{*}$ Summed features represent groups of two or three fatty acids that could not be separated by GLC with the MIDI system. Summed feature 2 contains $\mathrm{C}_{14: 0} 3-\mathrm{OH}$ and/or iso- $\mathrm{C}_{16: 1}$; summed feature 3 contains one or more of $\mathrm{C}_{16: 1} \omega 7 c, \mathrm{C}_{16: 1} \omega 6 c$ and iso- $\mathrm{C}_{15: 0} 2-\mathrm{OH}$.

an unknown aminolipid and phosphatidylcholine were identified as major polar lipids of $\mathrm{N}^{\mathrm{T}} 5^{\mathrm{T}}$ and were also present in the profile of $R$. rosea DSM $14916^{\mathrm{T}}$ (Fig. 1). Unlike $R$. rosea DSM $14916^{\mathrm{T}}$, strain $\mathrm{N} 75^{\mathrm{T}}$ did not contain the aminolipid AL1. Other differences were the presence in R. rosea DSM $14916^{\mathrm{T}}$ of several minor aminolipids, found close to the origin, indicating their relatively highly hydrophilic nature, and also detected in other species of the genus Roseomonas (Sánchez-Porro et al., 2009). Ubiquinone Q-10 was found in all strains. The DNA
$\mathrm{G}+\mathrm{C}$ content of strain $\mathrm{N}^{\mathrm{T}} 5^{\mathrm{T}}$ was $72.5 \mathrm{~mol} \%$ (Table 1 ), which is the highest $\mathrm{G}+\mathrm{C}$ molar percentage reported for this group.

The almost-complete $16 \mathrm{~S}$ rRNA gene sequence was determined for strain $\mathrm{N}^{2} 5^{\mathrm{T}}$ (1441 bp). The 16S rRNA gene sequence was aligned with those of representative members of the genus Roseomonas, including the type strains of the former Teichococcus ludipueritiae and Muricoccus roseus, both presently placed in the genus
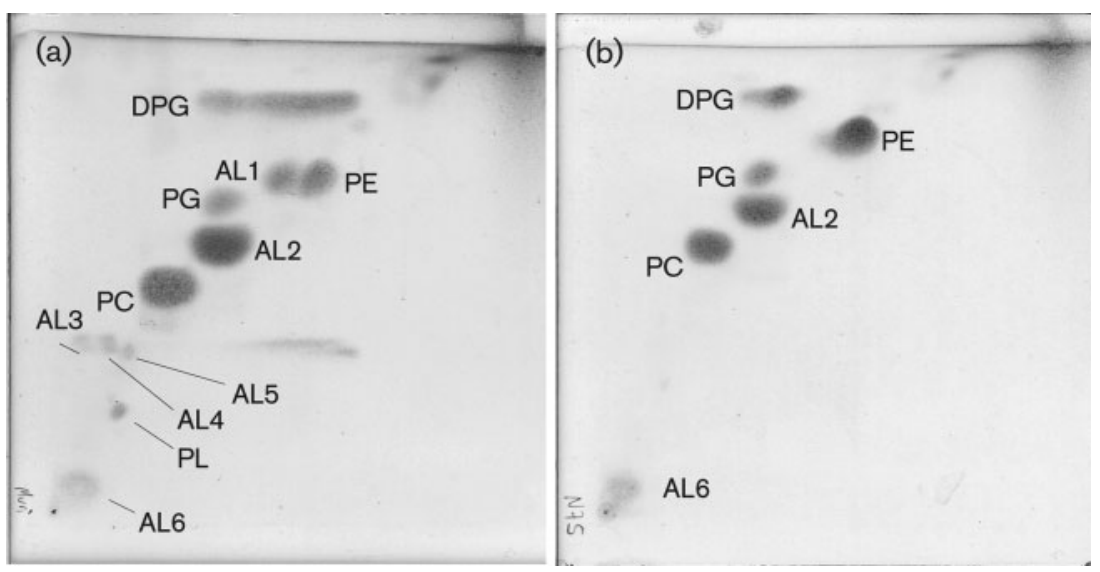

Fig. 1. Two-dimensional TLC of polar lipids of $R$. rosea DSM $14916^{\top}$ (a) and strain $\mathrm{N}^{\top} 5^{\top}$ (b). DPG, Diphosphatidylglycerol; PC, phosphatidylcholine; PE, phosphatidylethanolamine; $P G$, phosphatidylglycerol; AL1-6, unknown aminolipids; PL, unknown phospholipid. 


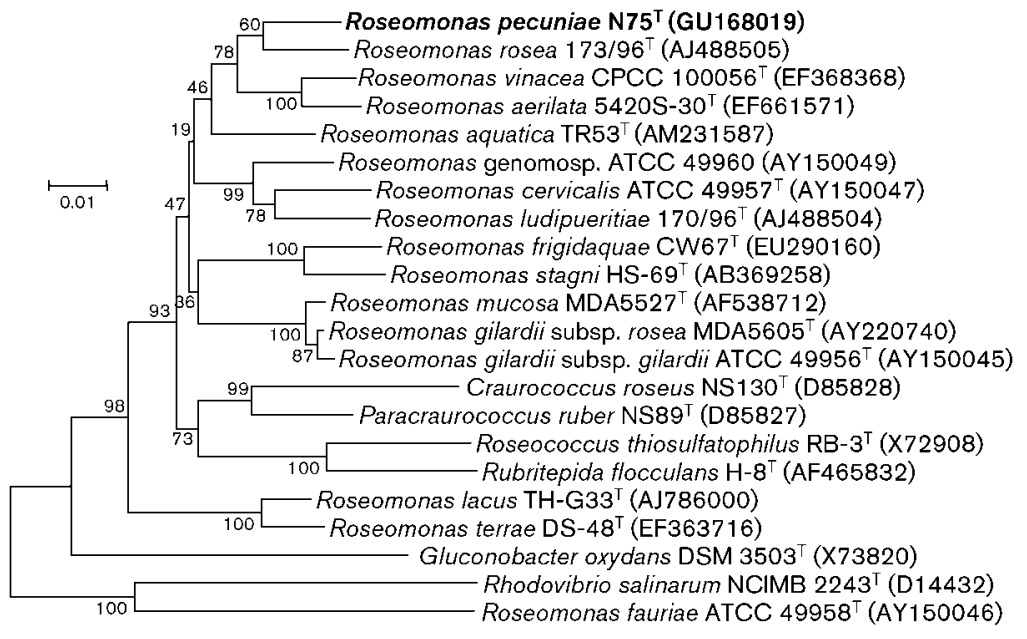

Fig. 2. Phylogenetic dendrogram based on $16 \mathrm{~S}$ rRNA gene sequences showing the relationships of strain $\mathrm{N} 75^{\top}$ and the closest related taxa. The dendrogram was reconstructed from evolutionary distances by using the neighbour-joining method and the topology was evaluated by performing bootstrap analysis of 1000 datasets; bootstrap values are given as percentages. Bar, 1 inferred substitution per 100 nucleotide positions.
Roseomonas (Sánchez-Porro et al., 2009). The sequence of strain $N 75^{\mathrm{T}}$ clustered with a sequence deposited in GenBank under accession number EF633683 (reported as Muricoccus sp. PC IW 03; A. Ruckmani and T. Chakrabarti, unpublished) at $99.7 \%$ similarity (not shown). Strain $\mathrm{N}^{2} 5^{\mathrm{T}}$ shared 16S rRNA gene sequence similarity of $97.1,96.9$ and $96.8 \%$ with $R$. rosea $173 / 96^{\mathrm{T}}, R$. aerilata $5420 \mathrm{~S}-30^{\mathrm{T}}$ and $R$. vinacea CPCC $100056^{\mathrm{T}}$, respectively (Fig. 2). The type strains of $R$. mucosa and the two subspecies of $R$. gilardii clustered with $\mathrm{N}^{\mathrm{T}} 5^{\mathrm{T}}$ at $95 \%$ similarity, and R. ludipueritiae $170 / 96^{\mathrm{T}}$ clustered with $\mathrm{N} 75^{\mathrm{T}}$ at less than $94 \%$ similarity. Different phylogenetic tree reconstructions always grouped strain $\mathrm{N} 75^{\mathrm{T}}$ with $R$. rosea $173 / 96^{\mathrm{T}}$, showing a stable phylogenetic relationship. Moreover, the phylogenetic analysis supported the suggestion made by Helsel et al. (2006) that the strains of $R$. fauriae should be transferred to A. brasilense, with the name Roseomonas fauriae being a later heterotypic synonym of Azospirillum brasilense.

The phenotypic traits that separate $\mathrm{N} 75^{\mathrm{T}}$ from its closest phylogenetic relative, $R$. rosea DSM $14916^{\mathrm{T}}$, are the higher $\mathrm{G}+\mathrm{C}$ content, the low diversity in lipid composition, the fatty acid profile, the absence of activity of leucine arylamidase, $\alpha$-chymotrypsin, urease and cytochrome oxidase, the weak ability to assimilate maltose and the lack of assimilation of capric acid and adipic acid when API $50 \mathrm{CH}$ was used and the ability to assimilate different substrates when the Biolog system GN2 was used. We propose that strain $N 75^{\mathrm{T}}$ represents a novel species of the genus Roseomonas, which we name Roseomonas pecuniae sp. nov.

\section{Description of Roseomonas pecuniae sp. nov.}

Roseomonas pecuniae (pe.cu'ni.ae. L. gen. n. pecuniae of/ from money or a coin, referring to the isolation of the type strain).

Colonies are small, smooth, convex, circular and pinkish red after 2 days of incubation on R2A. Similar colony morphology is observed on TSA. Growth occurs only in media without added $\mathrm{NaCl}$. Optimal growth at $30{ }^{\circ} \mathrm{C}$, with a temperature range of $10-35{ }^{\circ} \mathrm{C}$; does not grow at $37{ }^{\circ} \mathrm{C}$. Optimal growth at $\mathrm{pH}$ 7.0. Does not grow anaerobically. Gelatin is hydrolysed. Leucine arylamidase, $\alpha$-chymotrypsin, urease and cytochrome oxidase activities are not detected. Esterase lipase and naphthol-AS-BI-phosphohydrolase activities are detected. Weak acid production is obtained from maltose, malic acid and adipic acid using the API NE test strip; no other substrates are fermented or assimilated using API $50 \mathrm{CH}$. With the Biolog GN2 system, dextrin, L-rhamnose, sucrose, propionic acid and quinic acid are assimilated (Table 1). Nitrate is reduced to nitrite. Major fatty acids are $\mathrm{C}_{18: 1} \omega 7 c$ as the predominant fatty acid and $\mathrm{C}_{16: 0}$, summed feature 3 (one or more of $\mathrm{C}_{16: 1} \omega 7 c, \mathrm{C}_{16: 1} \omega 6 c$ and iso- $\left.\mathrm{C}_{15: 0} 2-\mathrm{OH}\right)$ and $\mathrm{C}_{12: 0}$. The fatty acid $\mathrm{C}_{18: 0} 3-\mathrm{OH}$ is present, but $\mathrm{C}_{19: 0}$ cyclo $\omega 8 \mathrm{c}$ is not. The major respiratory quinone is ubiquinone $10(\mathrm{Q}-10)$. The DNA G +C content of the type strain is $72.5 \mathrm{~mol} \%$ (determined by HPLC). The major polar lipids are phosphatidylcholine, phosphatidylethanolamine and an unknown aminolipid.

The type strain, $\mathrm{N} 75^{\mathrm{T}}\left(=\mathrm{LMG} 25481^{\mathrm{T}}=\mathrm{CIP} 110074^{\mathrm{T}}\right)$, was isolated from the surface of a 50 Euro cent copper-alloy coin.

\section{Acknowledgements}

This research was funded by the Fundação para a Ciência e Tecnologia (FCT), Portugal, under the POCTI and FEDER programs, contract POCTI/BSE/42414/2001. A. P. C. and C. E.-S. were supported by a grant from the FCT. G. G. was funded by the International Copper Association (ICA), New York, USA.

\section{References}

Branco, R., Alpoim, M. C. \& Morais, P. V. (2004). Ochrobactrum tritici strain 5 bvl1 - characterization of a $\mathrm{Cr}(\mathrm{VI})$-resistant and $\mathrm{Cr}(\mathrm{VI})$ reducing strain. Can J Microbiol 50, 697-703.

Cole, J. R., Chai, B., Marsh, T. L., Farris, R. J., Wang, Q., Kulam, S. A., Chandra, S., McGarrell, D. M., Schmidt, T. M. \& other authors 
(2003). The Ribosomal Database Project (RDP-II): previewing a new autoaligner that allows regular updates and the new prokaryotic taxonomy. Nucleic Acids Res 31, 442-443.

Collins, M. D., Goodfellow, M. \& Minnikin, D. E. (1980). Fatty acid, isoprenoid quinone and polar lipid composition in the classification of Curtobacterium and related taxa. J Gen Microbiol 118, 29-37.

Felsenstein, J. (1985). Confidence limits on phylogenies: an approach using the bootstrap. Evolution 39, 783-791.

Gallego, V., Garcia, M. T. \& Ventosa, A. (2006). Methylobacterium adhaesivum sp. nov., a methylotrophic bacterium isolated from drinking water. Int J Syst Evol Microbiol 56, 339-342.

Hall, T. A. (1999). BioEdit: a user-friendly biological sequence alignment editor and analysis program for Windows 95/98/NT. Nucleic Acids Symp Ser 41, 95-98.

Han, X. Y., Pham, A. S., Tarrand, J. J., Rolston, K. V., Helsel, L. O. \& Levett, P. N. (2003). Bacteriologic characterization of 36 strains of Roseomonas species and proposal of Roseomonas mucosa sp. nov. and Roseomonas gilardii subsp. rosea subsp. nov. Am J Clin Pathol 120, 256-264.

Helsel, L. O., Hollis, D. G., Steigerwalt, A. G. \& Levett, P. N. (2006). Reclassification of Roseomonas fauriae Rihs et al. 1998 as a later heterotypic synonym of Azospirillum brasilense Tarrand et al. 1979. Int J Syst Evol Microbiol 56, 2753-2755.

Jiang, C.-Y., Dai, X., Wang, B.-J., Zhou, Y.-G. \& Liu, S.-J. (2006). Roseomonas lacus sp. nov., isolated from freshwater lake sediment. Int J Syst Evol Microbiol 56, 25-28.

Jukes, T. H. \& Cantor, C. R. (1969). Evolution of protein molecules. In Mammalian Protein Metabolism, vol. 3, pp. 21-132. Edited by H. N. Munro. New York: Academic Press.

Kämpfer, P., Andersson, M. A., Jäckel, U. \& Salkinoja-Salonen, M. (2003). Teichococcus ludipueritiae gen. nov. sp. nov., and Muricoccus roseus gen. nov. sp. nov. representing two new genera of the $\alpha-1$ subclass of the Proteobacteria. Syst Appl Microbiol 26, 23-29.

Mesbah, M., Premachandran, U. \& Whitman, W. B. (1989). Precise measurement of the $\mathrm{G}+\mathrm{C}$ content of deoxyribonucleic acid by highperformance liquid chromatography. Int J Syst Bacteriol 39, 159-167.

Morais, P. V., Francisco, R., Branco, R., Chung, A. P. \& da Costa, M. S. (2004). Leucobacter chromiireducens sp. nov. and Leucobacter aridicollis sp. nov., two new species isolated from a chromium contaminated environment. Syst Appl Microbiol 27, 646-652.
Rihs, J. D., Brenner, D. J., Weaver, R. E., Steigerwalt, A. G., Hollis, D. G. \& Yu, V. L. (1993). Roseomonas, a new genus associated with bacteremia and other human infections. J Clin Microbiol 31, 32753283.

Rihs, J. D., Brenner, D. J., Weaver, R. E., Steigerwalt, A. G., Hollis, D. G. \& Yu, V. L. (1998). Roseomonas gen. nov. In Validation of the Publication of New Names and New Combinations Previously Effectively Published Outside the IJSB, List no. 65. Int J Syst Bacteriol 48, 627.

Saitou, N. \& Nei, M. (1987). The neighbor-joining method: a new method for reconstructing phylogenetic trees. Mol Biol Evol 4, 406425.

Sánchez-Porro, C., Gallego, V., Busse, H.-J., Kämpfer, P. \& Ventosa, A. (2009). Transfer of Teichococcus ludipueritiae and Muricoccus roseus to the genus Roseomonas, as Roseomonas ludipueritiae comb. nov. and Roseomonas rosea comb. nov., respectively, and emended description of the genus Roseomonas. Int J Syst Evol Microbiol 59, 1193-1198.

Smibert, R. M. \& Krieg, N. R. (1981). General characterization. In Manual of Methods for General Microbiology, pp. 409-443. Edited by P. Gerhardt, R. G. E. Murray, R. N. Costilow, E. W. Nester, W. A. Wood, N. R. Krieg \& G. B. Phillips. Washington, DC: American Society for Microbiology.

Tamura, K., Dudley, J., Nei, M. \& Kumar, S. (2007). MEGA4: molecular evolutionary genetics analysis (MEGA) software version 4.0. Mol Biol Evol 24, 1596-1599.

Thompson, J. D., Gibson, T. J., Plewniak, F., Jeanmougin, F. \& Higgins, D. G. (1997). The CLUSTAL_X windows interface: flexible strategies for multiple sequence alignment aided by quality analysis tools. Nucleic Acids Res 25, 4876-4882.

Tindall, B. J. (1989). Fully saturated menaquinones in the archaebacterium Pyrobaculum islandicum. FEMS Microbiol Lett 60, 251-254.

Yoo, S. H., Weon, H. Y., Noh, H. J., Hong, S. B., Lee, C. M., Kim, B. Y., Kwon, S. W. \& Go, S. J. (2008). Roseomonas aerilata sp. nov., isolated from an air sample. Int J Syst Evol Microbiol 58, 1482-1485.

Yoon, J. H., Kang, S. J., Oh, H. W. \& Oh, T. K. (2007). Roseomonas terrae sp. nov. Int J Syst Evol Microbiol 57, 2485-2488.

Zhang, Y. Q., Yu, L. Y., Wang, D., Liu, H. Y., Sun, C. H., Jiang, W., Zhang, Y. Q. \& Li, W. J. (2008). Roseomonas vinacea sp. nov., a Gramnegative coccobacillus isolated from a soil sample. Int J Syst Evol Microbiol 58, 2070-2074. 